\author{
Sławomir Wysocki*, Rafał Wiśniowski*, Magdalena Gaczoł**, \\ Wiktor Nowak**
}

\title{
THE INFLUENCE OF IONIC HYDRATION INHIBITORS ON DUAL INHIBITOR SYSTEM MUD PROPERTIES - CLAY ROCK SWELLING***
}

\section{INTRODUCTION}

Major issue during clay rock drilling is its swelling under the influence of the water obtained in mud. Therefore, in order to reduce the hydration of the rock, chemical agents are used in water-dispersive mud intended for clay drilling. Various inhibitor systema are being used. Ionic inhibitors are being applied next to polymeric agents and polyglycols. Nowadays, the most popular ionic inhibitor is potassium ion obtained from potassium chloride. The mechanism of this inhibitor is based on ion exchange. Potassium ions expel both calcium and sodium ions from the rock. The small size of the potassium ion, characterised by low hydration number, enables easy placement in interlayer spaces strongly bonding them. There is also the possible placement of potassium ion in the crystal lattice of a mineral. Simultaneously, substitution in tetragonal layers is limited due to a number of isomorphic substitutions, those bonds are very strong [1-3]. Field experience has shown that an ionic inhibitor's kind and concentration must be selected individually toward borehole conditions [1, 3-6].

In the project five different ionic inhibitors of clay rock hydration were examined. The studies include tests of inhibitors influence on both technological parameters of drilling muds with dual inhibitor system and swelling of the Miocene shale sample.

\section{FORMULA OF THE TEST MUD}

In order to conduct the studies of ionic hydration inhibitors influence on clay rock swelling, test mud was prepared. Further different ionic inhibitors were added to the mud. The generic formula of the mud developed for the studies is presented in Table 1.

\footnotetext{
* AGH University of Science and Technology, Faculty of Drilling, Oil and Gas, Krakow, Poland

** AGH University of Science and Technology, Faculty of Drilling, Oil and Gas, Krakow, Poland - PhD student

*** The research was supported by the Polish National Center for Research and Development, project Optidrilltec in Blue Gas Programme
} 
Table 1

Formula of the test mud

\begin{tabular}{|l|c|}
\hline \multicolumn{1}{|c|}{ Reagent } & Concentration [\%] \\
\hline PAC LV & 1 \\
\hline Rotomag & 2 \\
\hline XCD polymer & 0.01 \\
\hline PHPA PT-123/33 & 0.3 \\
\hline Ionic inhibitor & $0-7$ \\
\hline Carbonate bridging agent $30 \mu \mathrm{m}$ & 7 \\
\hline
\end{tabular}

In the studies following hydration inhibitors were applied:

- Mud-0: comparative mud without ionic inhibitor,

- Mud-1: KCl,

- Mud-2: $\mathrm{K}_{2} \mathrm{CO}_{3}$,

- Mud-3: HCOOK,

- Mud-4: $\mathrm{NH}_{4} \mathrm{Cl}$,

- Mud-5: $\mathrm{CaCl}_{2}$.

\section{METHODOLOGY OF THE RESEARCH}

In each case the influence of the non-ionic hydration's inhibitor on rheological properties, filtration, the lubricity coefficient and density of the test mud was examined (results are presented in [7]). Furthermore, the influence of the prepared muds on QSE Pellets swelling and Miocene shale linear swelling (LST) tests were performed.

Tests of mud technological parameters were conducted according to Polish and international standards (API Spec.) [8]. LST tests have been achieved with GRACE Instrument M4600 HPHT Linear Swell Meter. QSE Pellets swelling test involves the volume measurement of the initial pellet afterwards conditioned in the mud for $24 \mathrm{~h}$. After this time period, the second measurement was undertaken and the percentage increase of the volume was calculated.

\section{MUD-1 WITH KCI ADDITION}

The first of the tested non-ionic hydration inhibitors was potassium chloride. Test results are presented in Figures 1 and 2.

$1 \%$ of potassium chloride addition causes a significant reduction of QSE Pellets swelling. It has been noticed that further increase of $\mathrm{KCl}$ concentration leads to slight growth of tested pellets swelling.

The results show that by concentration increasing of the potassium chloride can be caused decrease of linear swelling (LST) of Miocene shale down to $12 \%$ in case of $7 \% \mathrm{KCl}$ addition. 

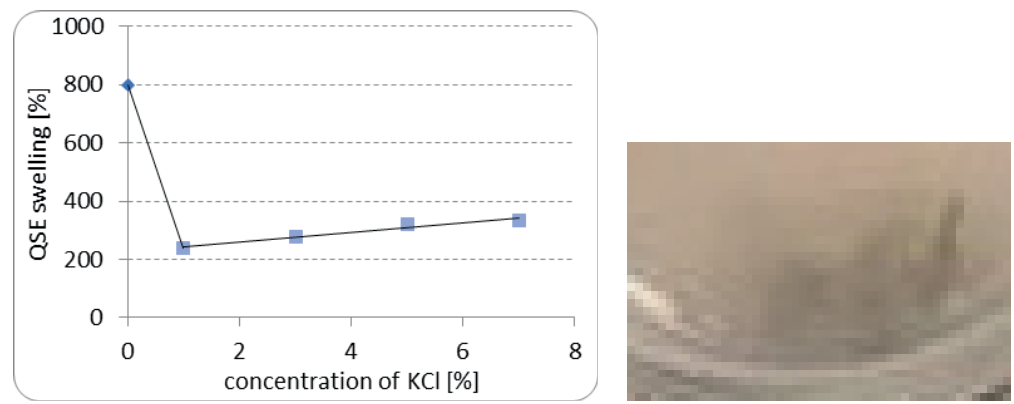

Fig. 1. QSE Pellets swelling under the influence of mud with $\mathrm{KCl}$ addition (photography - pellet condition for $7 \%$ of salt addition)

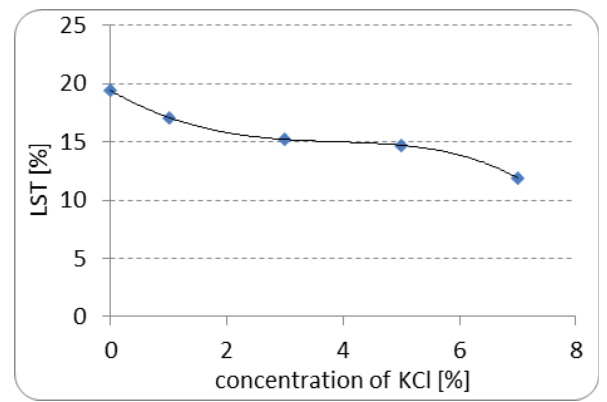

Fig. 2. Swelling (LST) of Miocene shale under the influence of mud with $\mathrm{KCl}$ addition

\section{MUD-2 WITH $\mathrm{K}_{2} \mathrm{CO}_{3}$ ADDITION}

Graphs (Figs 3-4) show test outcomes of test mud with the addition of potassium carbonate $\left(\mathrm{K}_{2} \mathrm{CO}_{3}\right)$ as an ionic inhibitor of hydration.
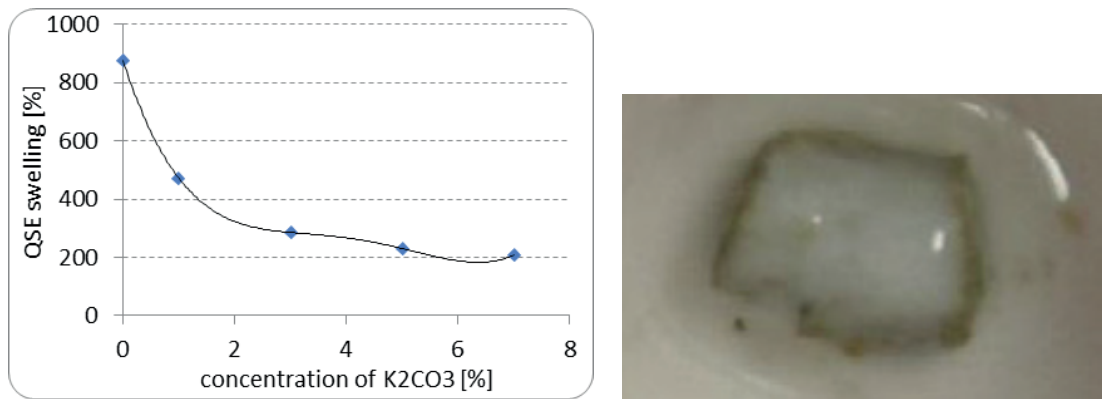

Fig. 3. QSE Pellets swelling under the influence of mud with $\mathrm{K}_{2} \mathrm{CO}_{3}$ addition (photography - pellet condition for $7 \%$ of salt addition)

Clay QSE Pellets swelling diminish considerably as the concentration of potassium carbonate increases. 


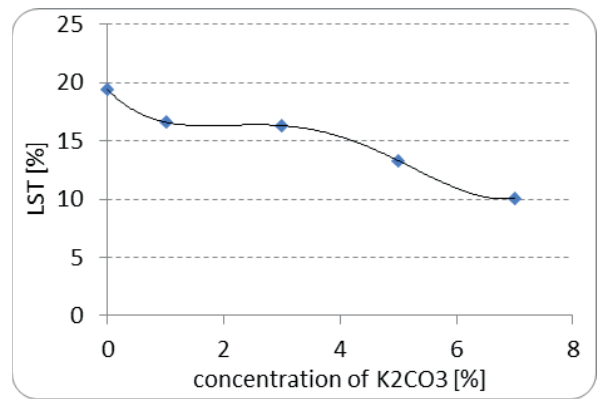

Fig. 4. Swelling (LST) of Miocene shale under the influence of mud with potassium carbonate addition

Tests of linear swelling (LST) of Miocene shale have showed that swelling is reduced due to an increase of potassium carbonate concentration and at $7 \%$ salt concentration reaches the value of $10 \%$.

\section{MUD-3 WITH HCOOK ADDITION}

Test findings of test mud with the addition of HCOOK as an ionic hydration inhibitor are presented in Figures 5 and 6.
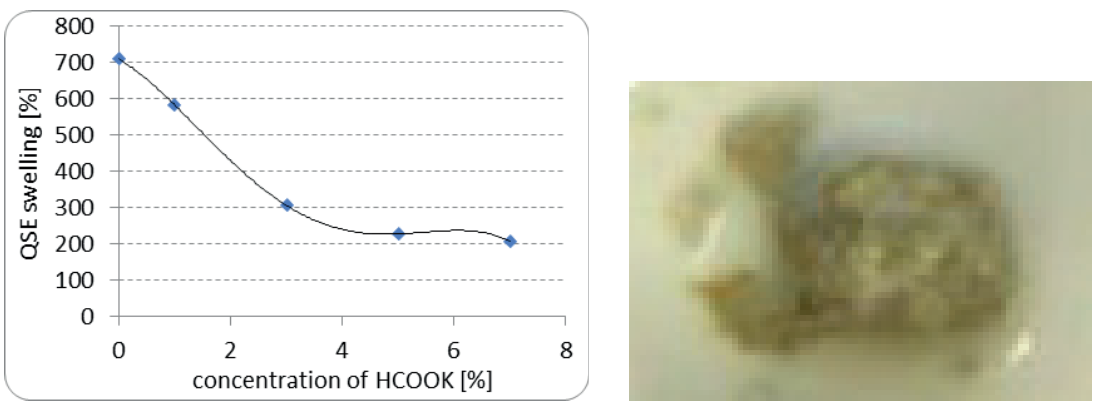

Fig. 5. QSE Pellets swelling under the influence of mud with HCOOK addition (photography - pellet condition for $7 \%$ of salt addition)

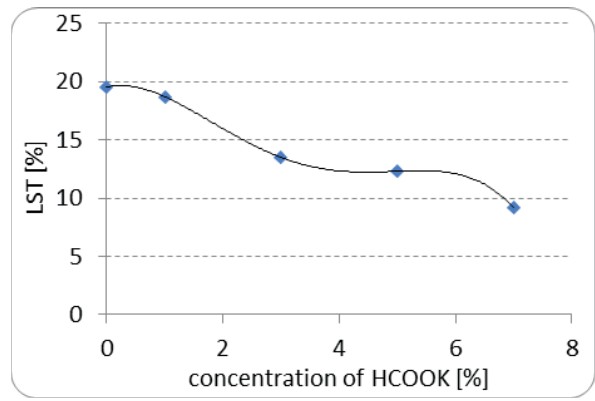

Fig. 6. Swelling (LST) of Miocene shale under the influence of mud with HCOOK addition 
$1 \%$ of potassium formate addition does not contribute to meaningful decrease of clay QSE Pellets swelling and Miocene shale linear swelling (LST). Yet, further increase of the inhibitor's concentration causes relevant reduction of clay swelling. The LST value for 7\% concentration of mud with potassium formate reaches $9 \%$.

\section{MUD-4 WITH NH$_{4}$ CI ADDITION}

Subsequent studied ionic inhibitor of hydration was ammonium chloride. Test outcomes are presented in Figures 7 and 8.
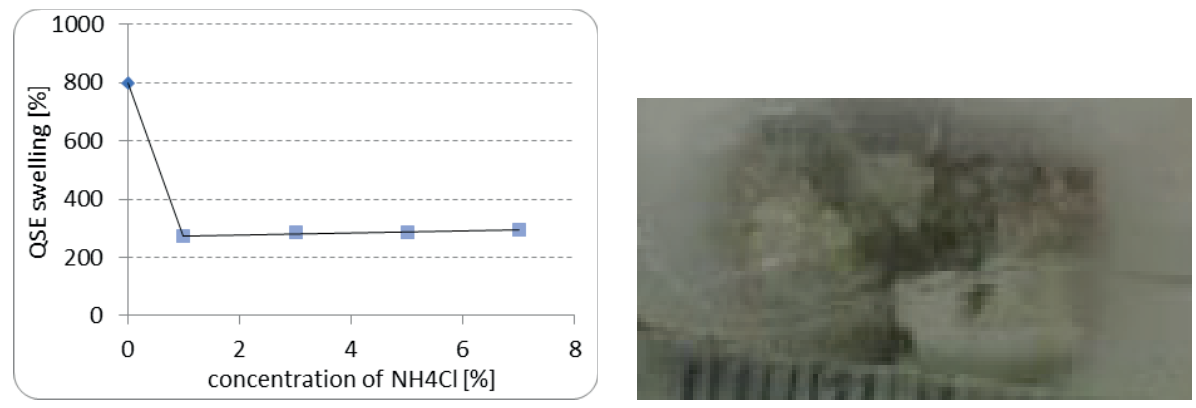

Fig. 7. QSE Pellets swelling under the influence of mud with $\mathrm{NH}_{4} \mathrm{Cl}$ addition (photography - pellet condition for $7 \%$ of salt addition)

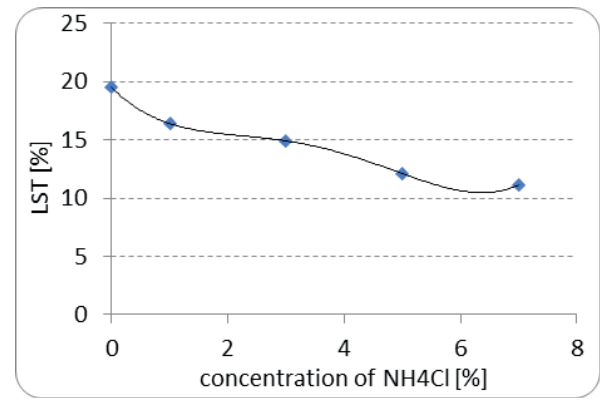

Fig. 8. Swelling (LST) of Miocene shale under the influence of mud with $\mathrm{NH}_{4} \mathrm{Cl}$ addition

Even 1\% of ammonium chloride addition causes a significant decrease of QSE Pellets swelling. Further $\mathrm{NH}_{4} \mathrm{Cl}$ concentration increase does not affects notably tested pellets swelling. An increase of ammonium chloride concentration in test mud causes gradual decrease of Miocene shale swelling. At $7 \%$ of salt concentration swelling reaches the value of $11 \%$. 


\section{MUD-5 WITH $\mathrm{CaCl}_{2}$ ADDITION}

Last studied non-ionic inhibitors of hydration was calcium chloride. Test results are presented in Figures 9 and 10.
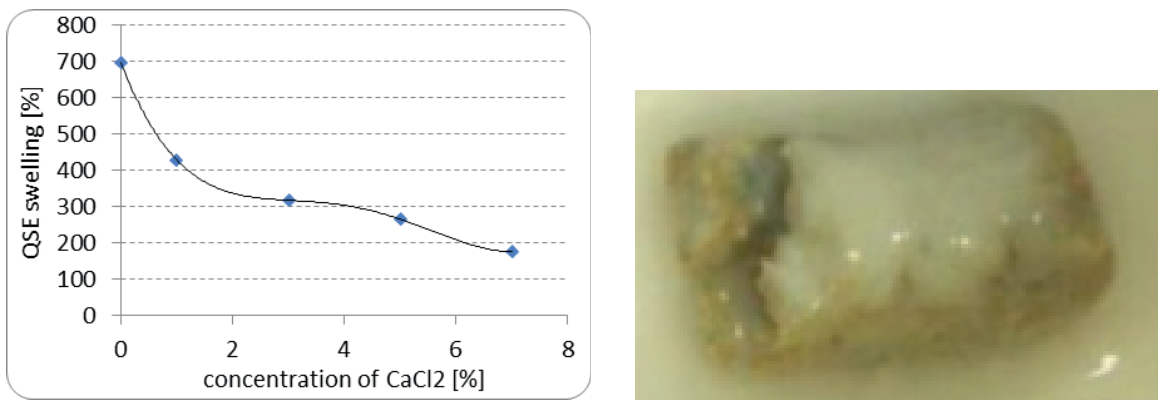

Fig. 9. QSE Pellets swelling under the influence of mud with $\mathrm{CaCl}_{2}$ addition (photography - pellet condition for $7 \%$ of salt addition)

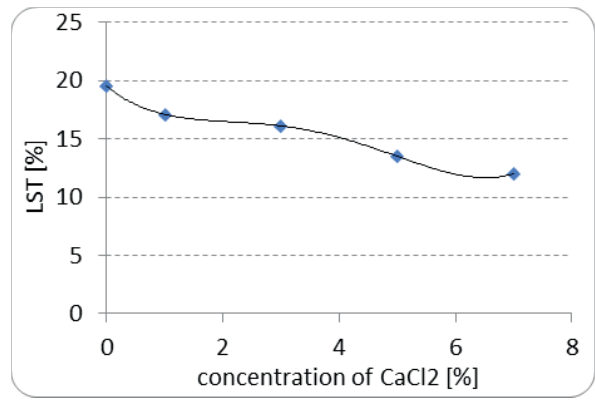

Fig. 10. Swelling (LST) of Miocene shale under the influence of mud with $\mathrm{CaCl}_{2}$ addition

An increase of calcium chloride concentration causes a gradual decrease of QSE Pellet samples swelling and Miocene shale linear swelling. At $7 \%$ of salt concentration linear swelling value reaches $13 \%$.

\section{TEST OF QSE PELLETS SWELLING - SUMMARY}

Test results of QSE Pellets swelling under the influence of mud with the addition of corrosion inhibitors are presented in Figure 11 and in Table 2.

Test results indicate that each of the hydration's inhibitors added to the mud in 3\% concentration diminish QSE Pellets swelling in a similar way. Muds with potassium chloride and ammonium chloride addition effectively decrease tested pellets swelling already at $1 \%$ concentration. A further increase of salt concentration does not consequence in better results. At $7 \%$ concentration the outcomes are worse than for different inhibitors. However, it was noticed that pellets conditioned in the mud with $\mathrm{KCl}$ addition are less cracked. 
Table 2

QSE Pellets swelling under the influence of mud with 3\% of ionic inhibitor addition

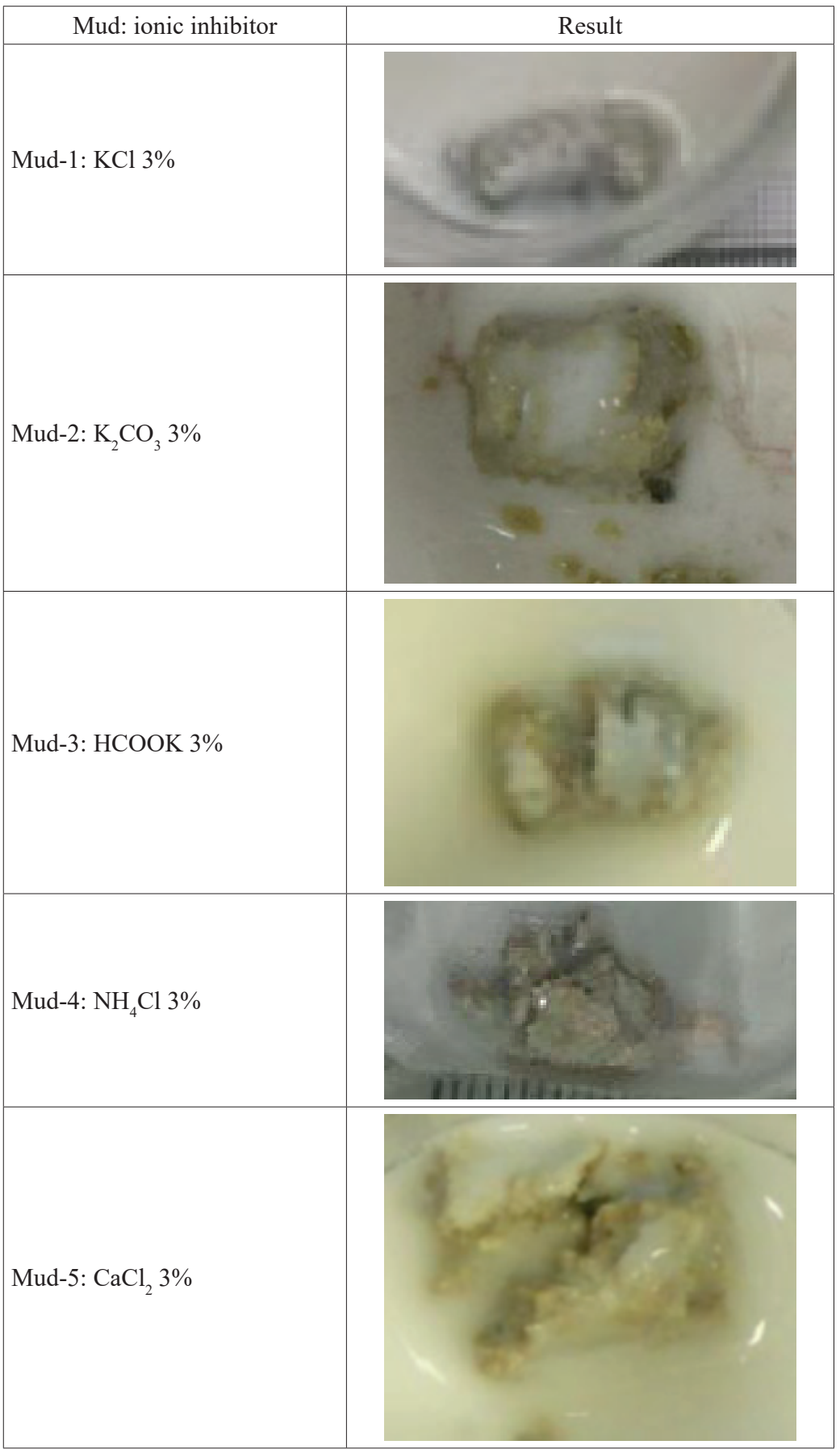




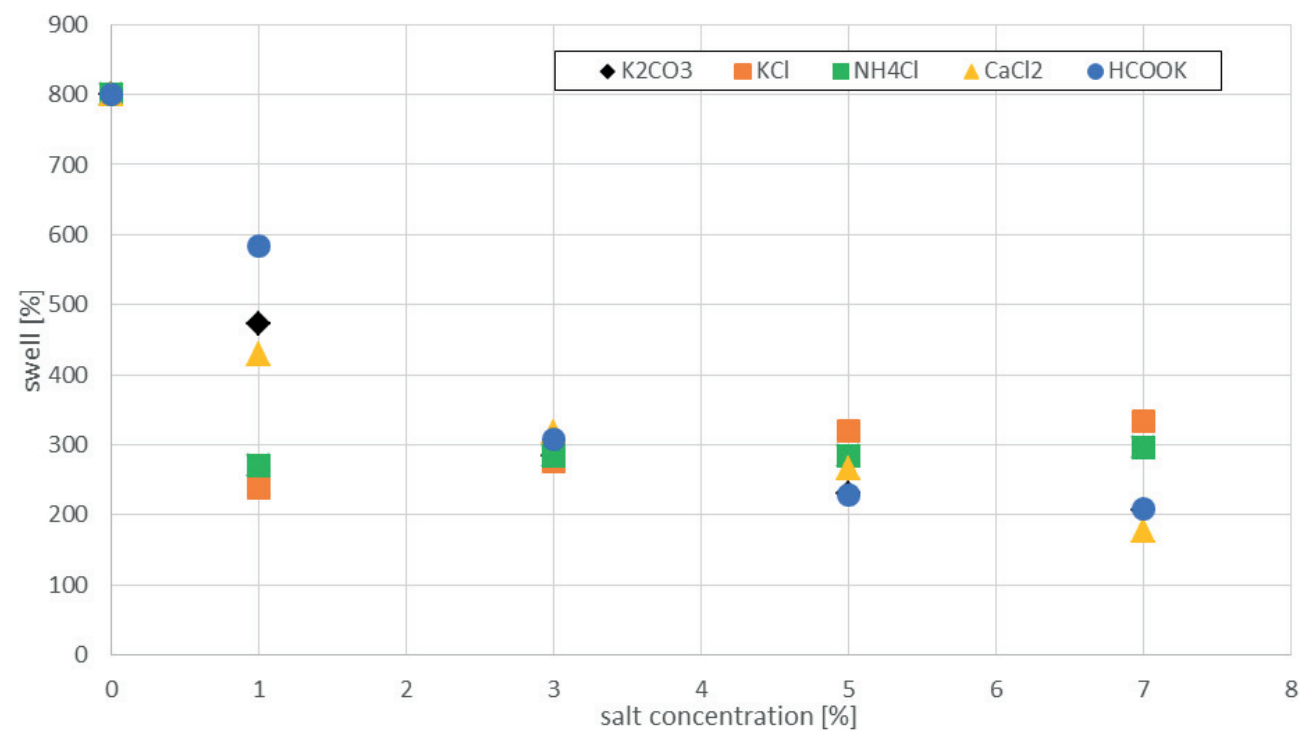

Fig. 11. QSE Pellets swelling under the influence of muds with the addition of ionic inhibitor

\section{TEST OF MIOCENE SHALE SWELLING}

Test outcomes of Miocene shale samples linear swelling (LST) under the influence of muds with ionic inhibitors addition are presented in Figure 12.

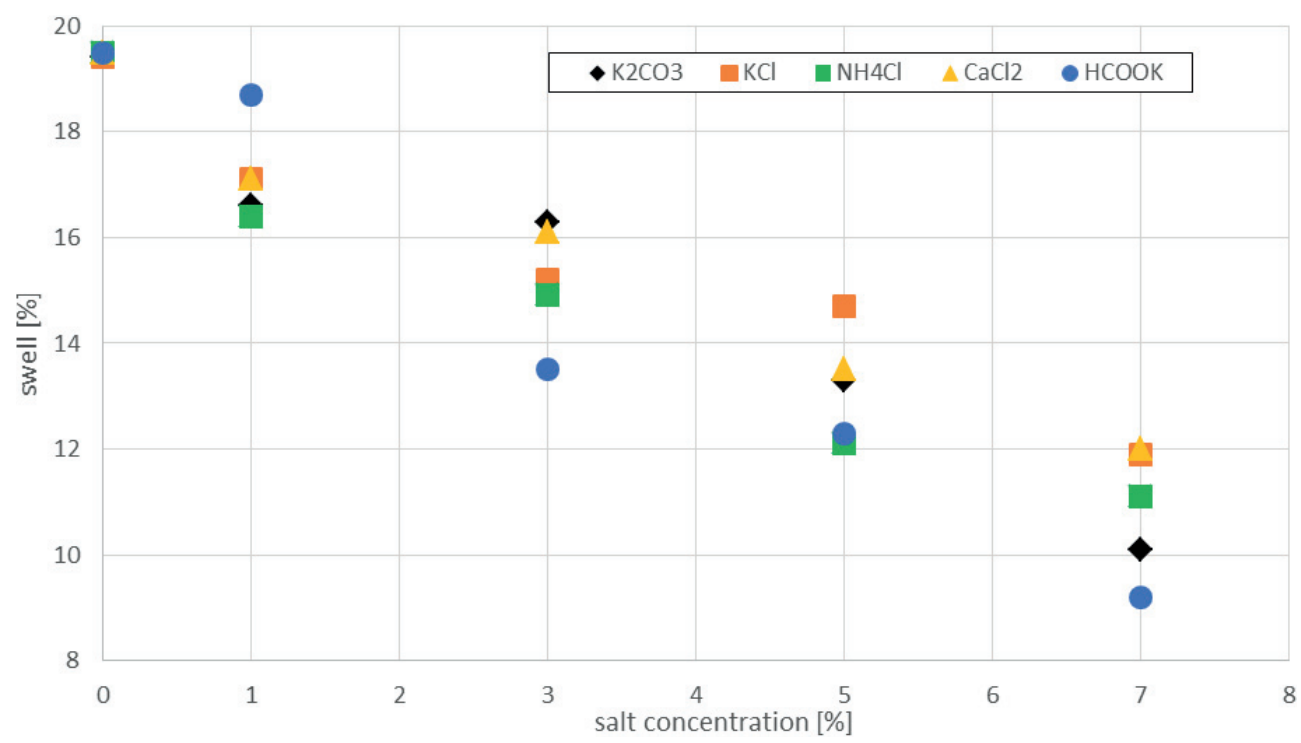

Fig. 12. Swelling (LST) of Miocene shale under the influence of muds with the addition of ionic inhibitor 
The undertaken tests showed that the most effective properties for the inhibition of Miocene shale swelling exhibits mud with $7 \%$ of ionic inhibitor addition. Amongst those potassium formate and potassium carbonate are the most effective. Mud with $7 \%$ addition reduces swelling at a comparable level as mud with $5 \%$ of formate potassium.

\section{CONCLUSIONS}

Currently, the most common clay rock hydration inhibitor is potassium chloride. Conducted tests show its effectiveness, however, potassium formate already at $3 \%$ concentration assures higher protection against clay rock swelling.

The application of potassium formate in drilling mud is advantageous in many ways. Formate mud is less corrosive than chloride mud. It also affects the environment in a less impactful way. Considering a lower amount of chlorides in the mud, formate mud is easier to utilize. A lower price of the potassium chloride is counterbalanced by the implementation of lower potassium formate concentration and achieving the same results.

\section{REFERENCES}

[1] Raczkowski J., Półchłopek T.: Materiały i środki chemiczne do sporządzania płuczek wiertniczych. Prace Instytutu Górnictwa Naftowego i Gazownictwa nr 95, Kraków 1998.

[2] Bielewicz D.: Plyny wiertnicze. Wydawnictwa AGH, Kraków 2009.

[3] Gray G.R., Darley H.C.H.: Composition and properties of oil welldrilling fluids. Gulf Publishing Company, Huston 1981.

[4] Carminati S., Del Gaudio L., Del Piero G., Brignoli M.: Water-Based Muds and Shale Interactions. SPE International Symposium on Oilfield Chemistry, Houston 2001, pp. 1-2.

[5] Gomez S., Patel A.: Shale Inhibition: What Works?. SPE International Symposium on Oilfield Chemistry, The Woodlands, 2013, pp. 1-3.

[6] Al-Arfaj M.K., Amanullah M., Sultan A.S., Hossain E., Abdulraheem A.: Chemical and mechanical Aspects of Wellbore Stability In Shale Formations: A Literature Review. International Petroleum Exhibition and Conference, Abu Dhabi 2014.

[7] Wysocki S., Wiśniowski R., Gaczoł M.: Wpływ stężenia jonowych inhibitorów hydratacji na właściwości płuczek o podwójnym systemie inhibicji-parametry technologiczne. AGH Drilling, Oil, Gas, vol. 33, no. 3, 2016, pp. 629-639.

[8] API Specification 13B-2, 5th edition, April 2014. 